\title{
How Prepared are we to Control Severe Acute Respiratory Syndrome in Future
}

\author{
Kanchan Bhardwaj \\ Department of Pediatrics, \\ All India Institute of Medical Sciences, Ansari Nagar, New Delhi, 110029, India
}

Received 2012-12-01, Revised 2012-12-10; Accepted 2013-07-20

\begin{abstract}
No non-human reservoirs for smallpox- and polio-viruses has contributed to the success of worldwide eradication of smallpox and a significant control of poliomyelitis. Most emerging and re-emerging viruses including SARS Coronavirus (SARS-CoV), have animal reservoirs and therefore, they impose a constant threat of host jump leading tooutbreaksin humans. It is desirable to be ready for control of infections that are caused by zoonotic pathogens, even after an outbreak has ended. This literature review is a compilation of advances made so far for diagnosis and treatment of SARS.
\end{abstract}

Keywords: SARS Coronavirus (SARS-CoV), Antivirals, Vaccines, Human Monoclonal Antibody

\section{INTRODUCTION}

According to the World Health Organization, there were 8,098 reported cases and 774 deaths worldwide during the Severe Acute Respiratory Syndrome (SARS) outbreak in2002-2003. First case of SARS appeared in November 2002 in Guangdong Province, China. By April2003, it had spread to around 30 countries including, Vietnam, Hong Kong, Singapore, Taiwan, India, Canada and United States of America.

On 24th March 2003, Center for Disease Controland Prevention, Atlanta, USA announced that the possible etiologic agent of SARS is either a human metapneumovirus or a previously unrecognized coronavirus. Shortly, it was confirmed to be a novel coronavirus based on electron microscopy, immunostaining, seroconversion as well as RT-PCR and sequencing of polymerase gene fragment (Drosten et al., 2003; Ksiazek et al., 2003). Availability and affordability of DNA sequencing facilitated genotyping of several isolates of SARS-CoV. By 29th April 2003, complete genome sequences of SARS-CoVisolates, Tor2, Urbani, HKU-39849, CUHK-W1 and KYK were posted on the web. Facilities at the BCCA Genome Sciences Centre in Vancouver, Centers for Disease Control and Prevention in Atlanta, University of Hong
Kong, Chinese University of Hong Kong, Genome Institute of Singapore and Beijing Genomics Institute were involved in thisseminal work. Many others are olates weresequencedand compared subsequently. The information obtained from such analyses was of epidemiologic significance. One, it revealed mutability of SARS-CoV, which, would have implications in vaccine development (Ruan et al., 2003; Tsui et al., 2003). Second, it led to the understanding that the organization of SARS-CoV genome is similar to the other coronaviruses although, at the primary sequence level, they were only distantly related (Rota et al., 2003). This ruled out the possibility of simple recombination event(s) among existing coronaviruses being responsible for the emergence of SARS-CoV. It was also indicative of the fact that this virus might have originated from animals. In fact, virus isolated from SARS patientswas able to cause a similar disease in cynomolgus macaques (Fouchier et al., 2003). Scientists began a search for the source of the SARS-CoV by scanning wild and domestic animals and indeed foundSARS virus-like coronaviruses from Himalayan palm civets and a raccoon dog found in a market in Guangdong, China. From sequence analysis, it was apparent that the viruses of human and civet origin shared more than 99\% homology. However, phylogenetic analysis of $\mathrm{S}$ proteins, placed viruses of 
human and civet origin in separate clusters. Also, the animalisolates contained a 29-nucleotide sequence in ORF 8 region that was absent in most human isolates (Guan et al., 2003).These analyses and the fact that palm civets did not show a widespread infection indicated that palm civetsmight not have been the natural reservoir host for SARS-CoV. Instead, they may have only served a medium to facilitate animal-to-human transition. This led to further searches inother animals including bats, rodents and monkeys for SARS-CoV host. SARS-CoV like viruses were found in bats. Sequence analysis showed that there was a significant homology between bat and human viruses. Interestingly, the 29-nucleotides in the ORF-8 was present in the virus of bat origin and the most variability between the two was found to be in the $\mathrm{S} 1$ region of spike protein, which is responsible for receptor binding ( $\mathrm{Li}$ et al., 2005a). Findings from all such studies were put together to establish origin of SARS-CoV. The most accepted theory is that bats are the natural reservoirs of SARS-CoV. Civets and other wild animals came in contact with SARS-CoV infected bats in a market, where theyacquired the virus. It evolved in these animals before hoping to animals. Major speciesspecific determinants are traced to the viral S protein.

Even after the outbreakcame under control, scientists around the world continued to treat the situationas urgent and have made significant advances in understanding the SARS-CoV biology, developing diagnostics, identifying a number of drug targets, potential antivirals, tools for vaccines and immunotherapy for SARS.

\subsection{Diagnostics}

Early and sensitive detection of SARS-CoV is important not only for treatment but also for control of disease spread. Initially, clinical symptoms and epidemiologic linkage were diagnostics for SARS followed by serologic testing, viral culture and PCRbased methods (Wu et al., 2003; Yam et al., 2003). Now, reagents are also available for Nucleocapsid (N) protein and Spike (S) protein detection (Che et al., 2004; Sunwoo et al., 2012).

\subsection{Antivirals}

During the outbreak, spread of SARS-CoV was predominantly controlled by surveillance and quarantine. Agents that were usually adaptedfor treatment were ribavirin, corticosteroids, human interferons (IFN- $\beta$ and IFN- $\gamma$ ) and convalescent plasma (Barnard et al., 2004; He et al., 2004; Keyaerts et al., 2004; Wu et al., 2004a;
Cinatl et al., 2005; Groneberg et al., 2005; Lai, 2005; Morgenstern et al., 2005; Saijo et al., 2005; Lau et al., 2006; Stockman et al., 2006). However, a systematic review of clinical trials and in vitro studies revealed that although agents such as ribavirin, corticosteroids, lopinavir and type I interferon showed inhibition of SARS-CoV in tissue culture, their usefulness was inconclusive in most patient studies (Stockman et al., 2006). Some studies have in fact shown possible harm from some of them (Lau et al., 2006; Stockman et al., 2006). Since then, several other small moleculeshave been investigated for effect on SARS-CoV in vitro and are listed with their observed effects in Table 1. In addition, progress made in understanding cellular and biochemical processes of the virus has allowed the identification of several novel antiviral targets and molecules to inhibit them.

\subsection{Entry Inhibitors}

Three important steps for SARS viral entry into the host cell include its binding to the host cells through an interaction between viral spike protein (S protein) and its receptor, the angiotensin-converting enzyme 2 (ACE 2) followed by conformational changes in the $\mathrm{S}$ protein and its activation by proteolysis. Agents that target these steps have been identified and analyzed for their inhibitory effects on SARS-CoV entry. Classes of entry inhibitor include siRNA to spike protein gene (Qin et al., 2004), peptides or recombinant proteins derived from $S$ protein (Ni et al., 2005; Sainz et al., 2006; Ujike et al., 2008; Struck et al., 2012) or ACE2 (Imai et al., 2005; Han et al., 2006), small molecules that bind S protein (Yi et al., 2004) and inhibitors of cellular protease (Simmons et al., 2005; Wang et al., 2007; Zhou et al., 2011). In addition, TNF- $\alpha$ Converting Enzyme (TACE) and lactoferrin bound to heparin sulfate proteoglycans have also been identified as targets for inhibition of viral entry (Haga et al., 2010; Lang et al., 2011).

\subsection{Viral Protease Inhibitors}

SARS viral replicase polyprotein is proteolytically processed by the viral proteases to generate functional enzymes. Owing to their essential role, 3CL protease, the main protease and the PapainLike Protease (PLP2) of SARS-CoV are considered important drug targets. Based on homology modeling using crystal structures for human coronavirus and an inhibitor complex of porcine coronavirus, Anand et al. (2003) proposed that rhinovirus 3C protease inhibitors might be modified for inhibiting SARS protease (Anand et al., 2003; Regnier et al., 2009). 
Table 1. Effect of antiviral agents on SARS-CoV in vitro

Agent
Calpain
Niclosamide
Aurintricarboxylic Acid (ATA)
Chloroquine
Nitric oxide
Hydrocortisone
Procyanidins and butanol
extracts of cinnamomi cortex
Synthetic peptides outside of
spike protein heptad
Dipeptide glutaminyl
fluoromethyl ketone
Cyclopentenyl carbocyclic
nucleosides
Indomethacin

Phenanthroindolizines

Emodin

Glycyrrhizin

Antisense Peptide Nucleic Acids (PNAs)

Antisense morpholino oligomers SiRNA
Major effects reported

A class of cellular cysteine proteinases that inhibited

SARS virus yield with an effective concentration in micro molar range (Barnard et al., 2004)

An existing antihelminthetic drug that abolished viral antigen synthesis at concentration of $1.56 \mathrm{uM}$ (Wu et al., 2004b)

ATA is known to inhibit protein and nucleic acid interaction. It was reported to be 10 or 100 times more potent inhibitor of SARS-CoV than IFN- $\propto$ and IFN- $\beta$, respectively (He et al., 2004) A clinically approved drug for malaria was effective with an IC50 in lower $\mu \mathrm{M}$ range (Keyaerts et al., 2004). In addition to its effect through elevation of endosomal $\mathrm{pH}$, chloroquine seems to interfere with terminal glycosylation of ACE2, the the receptor for SARS-CoV (Vincent et al., 2005)

Nitric oxide donor S-nitroso-N-acetylpenicillamine inhibited SARS-CoV by $2 \operatorname{logs}$ at $100 \mu \mathrm{M}$ (Akerstrom et al., 2005)

Only at very high concentrations, hydrocortisone showed a moderate effect on chemokine production by SARS-CoV (Cinatl et al., 2005)

A moderate inhibitory activity in wild-type SARS-CoV and HIV/SARS-CoV pseudovirus assay is reported (Zhuang and Jiang, 2009)

$\mathrm{S}$ protein fragments spanning sequence variation hotspots reduced SARS-CoV infectivity significantly (Guan et al., 2003)

An inhibition with EC50 value in low $\mu$ molar range is observed (Zhang et al., 2008)

1,2,3-trizole analogs which, exhibited an antiviral activity with an

EC50 of $21 \mu \mathrm{M}$ or $47 \mu \mathrm{M}$ (Cho and Bernard, 2006)

Inhibits viral RNA synthesis with $>1,000$ fold reduction in

CCo-V infected dogs (Amici et al., 2006)

Tylophorine compounds inhibited SARS-CoV with

EC50 in nM range (Yang et al., 2010)

Emodin is shown to inhibit SARS-CoV via its ion channel protein, 3a (Schwarz and Wang, 2011)

Glycyrrhizin inhibits SARS but some of its derivatives showed reduced specificity (Hoever and Baltina, 2005)

PNAs that were targeted to interfere with programmed -1 ribosomal shifting and fused to cell penetrating peptides resulted in inhibition of SARS-CoV replication with IC50 of $4.4 \mu \mathrm{M}$ (Ahn et al., 2011)

Oligomers targeted to Transcription-Regulatory Sequence (TRS) are reported to show a low inhibitory activity against SARS-CoV (Neuman et al., 2005) siRNAs for various targets including, interferons, leader sequence or $\mathrm{N}$ protein have been tested (Li et al., 2005a; 2005b; Wu and Huang, 2005;

Zhao and Qin, 2005; Tang and Li, 2008)
Homology modeling also formed a basis for designing mechanism-based irreversible inhibitors of 3CLpro with an activity of wide spectrum across coronaviruses (Yang et al., 2005a). Besides, several groups have identified a number of inhibitors of 3CLpro using a variety of approaches. Virtual screening (Plewczynski et al., 2007; Mukherjee et al., 2008; 2011; Nguyen et al., 2011) or a high-throughput screening of small molecule libraries have identified inhibitorsincluding an anti-HIV agent and serotonin antagonist, cinanserin (Blanchard et al., 2004; Kao et al., 2004; Wu et al., 2004a; Chen et al., 2005). Other
3CL protease inhibitors identified so far belongto categories such as plant derived phenolic or flavonoid compounds (Lin et al., 2005; Nguyen et al., 2012), active site, nonactive site or competitive inhibitors (Kaeppler et al., 2005; Lee et al., 2005; Du et al., 2007; Ryu et al., 2010), ketones or ester based inhibitors (Goetz et al., 2007; Zhang et al., 2007; Ghosh et al., 2008; Shao et al., 2008; Verschueren et al., 2008; Zhang et al., 2008), modified peptidomimetic inhibitors (Ghosh et al., 2007), metal conjugated inhibitors (Lee et al., 2007; 2009), common inhibitors of Corona and Picornaviruses 
(Kuo et al., 2009) and pyrimidines (Ramajayam et al., 2010). Protease inhibitors have also been reviewed elsewhere (Liang, 2006; Ramajayam et al., 2011).

In addition to its role in proteolytic processing of the viral polymerase, PLP2 is also involved in host evasion. Some of the first identified small molecule lead compounds for inhibition of PLP2 were thiopurine analogs (Chou et al., 2008; Chen et al., 2009). Besides, Ratia et al. (2008) have synthetically evolved a noncovalent inhibitor demonstrating an $\mathrm{IC}_{50}$ of around $15 \mu \mathrm{M}$ in a cell based SARS-CoV replication assay (Ratia et al., 2008). Dooley et al. (2006) and Ghosh et al. (2009) have identified small molecules with $\mathrm{EC}_{50}$ valuesin lower micromolar range (Dooley et al., 2006; Ghosh et al., 2009). Recently, a yeast-based assay for measurement of papain-like protease activity that is suitable for screening of inhibitors was established (Frieman et al., 2011).

\subsection{Helicase Inhibitors}

Bismuth complexes and RNA aptamers have been shown to inhibit activity of SARS-CoV helicase (Yang et al., 2007; Jang et al., 2008; Adedeji et al., 2012; Keum and Jeong, 2012).

\subsection{Host Pathway Inhibitors}

Although, inhibitors of viral proteins have been used for treating some other viral infections, asignificant issue with targeting the viral proteins has been the development of drug resistant virus. This is likely due to the selection of mutant virus under drug pressure. Inhibitors of host systems, including immune and housekeeping, that may be critical for virus survival are alternatives that are worth an investigation. Cyclosporine and FK506 have emerged as examples of such inhibitors (De Wilde et al., 2011; Pfefferle et al., 2011; CarbajoLozoya et al., 2012). Other host pathway proteinsthat are potential antiviral drug targets have been identified (Ma et al., 2010; Bhardwaj et al., 2012; Millet et al., 2012; Smith et al., 2012; Zhao et al., 2012).

\subsection{Vaccines and Immunotherapy for SARS-CoV}

Coronaviruses cause significant infections in humans and animals. Although, no vaccines against coronaviruses are available at this time for use in human, they are produced for use in animals (Olsen et al., 1993; Anton et al., 1996). A need for prophylactic treatment ora vaccine is underscored by what happened during the 2002-2003 SARS outbreak. In the Vietnamese outbreak of SARS, all patients who died apart from the index patient were healthcare professionals including a WHO scientist, Dr. Carlo Urbani. It was Dr. Urbani's initiatives that led to the successful containment of the disease in Hanoi. He died of SARS on March 29th 2003.

Roberts et al. (2008) and Roper and Rehm (2009) have reviewed the SARS animal models and the initial vaccine studies in great detail (Roberts et al., 2008; Roper and Rehm, 2009). Several animal models that have been developed for SARS vaccine studies include mice, African green monkey, ferrets, macaques, hamsters and Chinese masked palm civet. Multiple labshave demonstrated the feasibility of various types of vaccines (Table 2). However, vaccine efficacy and safety issues are still being investigated (Table 2). Studies related to SARS vaccinehave taught us several lessons about pathogenesis and host responses to SARS-CoV, in addition to unraveling the need for caution. With certain experimental vaccines, such as the viral vector based ones, immunopathology and redirection of the viral vector to brain was reported (Czub et al., 2005; Deming et al., 2006; Kam et al., 2007; Jaume et al., 2011; Tseng et al., 2012). Subsequent studies demonstrated that a sub lingual immunization can prevent the viral vector entry into the brain (Shim et al., 2012). Also, an intranasal route of vaccination was shown to protect mice from SARS-CoV challenge better than an intramuscular delivery of the same vaccine (See et al., 2006; Hu et al., 2007). Expression of full length $\mathrm{S}$ protein is shown to result in enhanced hepatitis or infection whereas, expression of just the ectodomain of $\mathrm{S}$ protein eliminated infection enhancement (Weingartl et al., 2004; Yang et al., 2005b). All these reports point to that it will be important to establishan appropriatecombination of vaccination route, vaccine vector andchoice of epitopes for each vaccine type.SARS vaccines thatgeneratea predominantly cellular or a predominantly humoral response, as well as therapeutic monoclonal antibodies, have been shown protectiveeffects in animal models. Therefore, what kind of responses are important for protection has not been clear (Subbarao et al., 2004; Zakhartchouk et al., 2005; Lin et al., 2007; See et al., 2008; Zhao and Perlman, 2010). Cameron et al. (2012) have recently reported an analysis of transcripts expressed during SARS-CoV infection in vaccination and reinfectiontrials in ferrets (Cameron et al., 2012). Such studies can potentially reveal new therapeutic options in addition to providing the basic understanding of host responses during infection, vaccination and re-infection. 
Table 2. Experimental vaccines for SARS

\begin{tabular}{|c|c|c|}
\hline Vaccine type & Safety & Efficacy \\
\hline Inactivated virus & $\begin{array}{l}\text { Safe and immunogenic in humans } \\
\text { (Lin et al., 2007). Hypersensitive } \\
\text { reaction upon post-immunization viral } \\
\text { challenge in mice (Kam et al., 2007; } \\
\text { Tseng et al., 2012) }\end{array}$ & $\begin{array}{l}\text { Efficacy needs to be established in } \\
\text { appropriate animal model (See } \text { et al., 2008) }\end{array}$ \\
\hline $\begin{array}{l}\text { Recombinant vector } \\
\text { Vaccines (Adenovirus, } \\
\text { Poxvirus or recombinant) }\end{array}$ & $\begin{array}{l}\text { Disease exacerbation upon SARS-CoV } \\
\text { challenge in some cases (Czub et al., 2005) }\end{array}$ & $\begin{array}{l}\text { Protective in mice, ferrets, monkeys, } \\
\text { hamsters (Bukreyev et al., 2004; } \\
\text { See } \text { et al., 2006; } \\
\text { Napoli et al., 2007; See et al., 2008) }\end{array}$ \\
\hline $\begin{array}{l}\text { Subunit or virus like } \\
\text { particle vaccines }\end{array}$ & $\begin{array}{l}\text { Immunopathology is observed in some cases } \\
\text { (Kam et al., 2007; Jaume et al., 2011; } \\
\text { Tseng et al., 2012). Hypersensitive } \\
\text { reaction upon post-immunization viral challenge } \\
\text { in mice (Kam et al., 2007; Tseng et al., 2012) }\end{array}$ & $\begin{array}{l}\text { Protective in hamsters and ferrets } \\
\text { (Kam et al., 2007; Tseng et al., 2012) }\end{array}$ \\
\hline DNA vaccines & $\begin{array}{l}\text { Safe and immunogenic in healthy humans } \\
\text { (Martin et al., 2008). Hypersensitive reaction } \\
\text { upon post-immunization viral challenge in mice } \\
\text { (Kam et al., 2007; Tseng et al., 2012) }\end{array}$ & Protective in mice (Yang et al., 2004) \\
\hline Attenuated vaccines & Safety needs to be established & $\begin{array}{l}\text { E protein lacking-or ExoN mutant vaccine } \\
\text { is immunogenic and efficacious } \\
\text { (Lamirande } \text { et al., 2008; Graham et al., 2012) }\end{array}$ \\
\hline
\end{tabular}

\section{CONCLUSION}

Although, a myriad of compounds have been identified to show inhibitory effects on SARS-CoVin vitro, only a few of those are reported for their safety and efficacy in animal models. Of the tested compounds, a hybrid interferon alpha (IFN- $\alpha$ ) and an IFN- inducer, a mismatch double stranded RNA, have shown potent inhibition of SARS-CoV replication in the lungs of infected mice (Barnard et al., 2006). It would be useful and desirable to evaluate the other compounds in animal models for their safety and efficacy. With identification of epitopes that will not generate antibodies cross-reactive to self-antigens andcare taken to eliminate antibody dependent enhancement of disease, therapeutic use of human monoclonal antibodies seems a promising option for SARS. Coughlin and Prabhakar (2012) have reviewed the human monoclonal antibodiesgenerated for antiSARS therapy (Coughlin and Prabhakar 2012). For active immunization, efficacy of the developed vaccines needs to be established in a most relevant disease model. Efforts have gone into improving animal models for SARS; however, they still have limitation.

A novel SARS-like human coronavirus, HCoVEMC/2012 was identified earlier this year ( $\mathrm{Lu}$ and Liu, 2012; Boheemen et al., 2012). Although, HCoVEMC/2012 is only distantly related to SARS-CoV, the knowledge and reagents acquired from SARS-CoV research may prove useful in understanding and controlling this novel and other coronavirus (Elshabrawy et al., 2012; Graham et al., 2012).

\section{ACKNOWLEDGMENT}

I acknowledge Dr. Ranjith-Kumar C.T of Translational Health Science and Technology Institute, Gurgaon, India and Dr. Ramesh Agarwal of All India Institute of Medical Sciences, New Delhi, India for editing the manuscript.

\section{REFERENCES}

Adedeji, A.O., K. Singh, K. Singh, N.E. Calcaterra and M. L. DeDiego et al., 2012. Severe acute respiratory syndrome coronavirus replication inhibitor that interferes with the nucleic acid unwinding of the viral helicase. Antimicrob. Agents Chemotherapy, 56: 4718-4728. DOI: 10.1128/AAC.00957-12

Ahn, D.G. and W. Lee, J.K. Choi, S.J. Kim E.P. Plant and F. Almazan, 2011. Interference of ribosomal frameshifting by antisense peptide nucleic acids suppresses SARS coronavirus replication. Antiviral Res., 91: 1-10. DOI: 10.1016/j.antiviral.2011.04.009 Akerstrom, S., M. Mousavi-Jazi, J. Klingström, M. Leijon and A. Lundkvist et al., 2005. Nitric oxide inhibits the replication cycle of severe acute respiratory syndrome coronavirus. J. Virol., 79: 1966-1969. DOI: 10.1128/JVI.79.3.1966-1969.2005 
Amici, C. and A.D. Coro, A. Ciucci and L. Chiappa 2006. Indomethacin has a potent antiviral activity against SARS coronavirus. Antiviral Therapy, 11: 1021-1030. PMID: 17302372

Anand, K., J. Ziebuhr, P. Wadhwani, J.R. Mesters and R. Hilgenfeld et al., 2003. Coronavirus main proteinase $\left(3 \mathrm{CL}^{\mathrm{pro}}\right)$ structure: Basis for design of anti-SARS drugs. Science, 300: 1763-1767. DOI: 10.1126/science. 1085658

Anton, I.M., S. Gonzalez, M.J. Bullido, M. Corsin and C. Risco et al., 1996. Cooperation between Transmissible Gastroenteritis Coronavirus (TGEV) structural proteins in the in vitro induction of virusspecific antibodies. Virus Res., 46: 111-124. DOI: 10.1016/S0168-1702(96)01390-1

Barnard, D. L., V. D. Hubbard, J. Burton, D.F. Smee and J.D. Morrey et al., 2004. Inhibition of severe acute respiratory syndrome-associated coronavirus (SARSCoV) by calpain inhibitors and beta-D-N4hydroxycytidine. Antivir. Chem. Chemother., 15: 15-22. PMID: 15074711

Barnard, D.L., C.W. Day, K. Bailey, M. Heiner and R. Montgomery, et al., 2006. Evaluation of immunomodulators, interferons and known in vitro SARS-coV inhibitors for inhibition of SARS-coV replication in BALB/c mice. Antivir. Chem. Chemother., 17: 275-284. PMID: 17176632

Bhardwaj, K., P. Liu, J.L. Leibowitz and C.C. Kao, 2012. The coronavirus endoribonuclease Nsp15 interacts with retinoblastoma tumor suppressor protein. J. Virol., 86: 4294-4304. DOI: 10.1128/JVI.07012-11

Blanchard, J.E., N.H. Elowe, C. Huitema, P.D. Fortin and J.D. Cechetto et al., 2004. High-throughput screening identifies inhibitors of the SARS coronavirus main proteinase. Chem. Biol., 11: 14451453. DOI: 10.1016/j.chembiol.2004.08.011

Boheemen, S.V., M.D. Graaf, C. Lauberb, T.M. Bestebroera and V.S. Raja et al., 2012. Genomic characterization of a newly discovered coronavirus associated with acute respiratory distress syndrome in humans. mBio, 3: e00473-e00473. DOI: 10.1128/mBio.00473-12

Bukreyev, A., E.W Lamirande, U.J. Buchholz, L.N. Vogel and W.R. Elkins et al., 2004. Mucosal immunisation of African green monkeys (Cercopithecus aethiops) with an attenuated parainfluenza virus expressing the SARS coronavirus spike protein for the prevention of SARS. Lancet, 363: 2122-2127. DOI: 10.1016/S0140-6736(04)16501-X
Cameron, M.J., A.A. Kelvin, C.M. Cameron, L. Ran and S.G. Paquette et al., 2012. Lack of Innate Interferon Responses during SARS coronavirus infection in a vaccination and reinfection ferret model. PloS One, 7: e45842-e45842.

Carbajo-Lozoya, J., M.A. Muller, S. Kallies, V. Thiel and C. Drosten et al., 2012. Replication of human coronaviruses SARS-CoV, HCoV-NL63 and HCoV$229 \mathrm{E}$ is inhibited by the drug FK506. Virus Res., 165: 112-117. DOI: 10.1016/j.virusres.2012.02.002

Che, X.Y., W. Hao, Y. Wang, Y.C. Xu and C.S. Feng et al., 2004. Nucleocapsid protein as early diagnostic marker for SARS. Emerg. Infect. Dis., 10: $1947-$ 1949. DOI: 10.3201/eid1011.040516

Chen, L., C. Gui, X. Luo, Q. Yang and S. Gunther et al., 2005. Cinanserin is an inhibitor of the 3C-like proteinase of severe acute respiratory syndrome coronavirus and strongly reduces virus replication in vitro. J. Virol., 79: 7095-7103. DOI: 10.1128/JVI.79.11.7095-7103.2005

Chen, X., C.Y. Chou and G.G. Chang, 2009. Thiopurine analogue inhibitors of severe acute respiratory syndrome-coronavirus papain-like protease, a deubiquitinating and deISGylating enzyme. Antivir. Chem. Chemother., 19: 151-156. PMID: 19374142

Cho, J.H. and D.L. Bernard, 2006. Synthesis of cyclopentenyl carbocyclic nucleosides as potential antiviral agents against orthopoxviruses and SARS. J. Med. Chem., 49: 1140-1148. DOI: 10.1021/jm0509750

Chou, C.Y., C.H. Chien, Y.S Han M.T. Prebanda and H.P. Hsieh et al., 2008. Thiopurine analogues inhibit papain-like protease of severe acute respiratory syndrome coronavirus. Biochem. Pharmacol., 75: 1601-1609. DOI: 10.1016/j.bcp.2008.01.005

Cinatl, J. Jr., C.J., M. Michaelis, M. Michaelis, G. Hoever and W. Preiser et al., 2005. Development of antiviral therapy for severe acute respiratory syndrome. Antivir. Res., 66: 81-97. DOI: 10.1016/j.antiviral.2005.03.002

Coughlin, M.M. and B.S. Prabhakar, 2012. Neutralizing human monoclonal antibodies to severe acute respiratory syndrome coronavirus: Target, mechanism of action and therapeutic potential. Rev. Med. Virol., 22: 2-17. DOI: 10.1002/rmv.706

Czub, M., H. Weingartl, S. Czub, R. He and J. Cao et al. 2005. Evaluation of modified vaccinia virus Ankara based recombinant SARS vaccine in ferrets. Vaccine, 23: 2273-2279. DOI: 10.1016/j.vaccine.2005.01.033 
De Wilde, A.H., J.C. Zevenhoven-Dobbe, Y.V.D. Meer, V. Thiel and K. Narayanan et al., 2011. Cyclosporin A inhibits the replication of diverse coronaviruses. J. General Virol., 92: 2542-2548. DOI: 10.1099/vir.0.034983-0

Deming, D., T. Sheahan, M. Heise, B. Yount and N. Davis et al., 2006. Vaccine efficacy in senescent mice challenged with recombinant SARS-CoV bearing epidemic and zoonotic spike variants. PLoS Med., 3: e525-e525. DOI: 10.1371/journal.pmed.0030525

Dooley, A.J., N. Shindo, B. Taggart, J.G. Park and Y.P. Pang et al., 2006. From genome to drug lead: Identification of a small-molecule inhibitor of the SARS virus. Bioorganic Med. Chem. Lett., 16: 830833. PMID: 16325400

Drosten, C., S. Gunther, W. Preiser, S.V.D. Werf and H.R. Brodt et al., 2003. Identification of a novel coronavirus in patients with severe acute respiratory syndrome. New England J. Med., 348: 1967-1976. DOI: 10.1056/NEJMoa030747

Du, Q.S., H. Sun and K.C. Chou, 2007. Inhibitor design for SARS coronavirus main protease based on "Distorted key theory". Med. Chem., 3: 1-6. DOI: 10.2174/157340607779317616

Elshabrawy, H.A., M.M. Coughlin, S.C. Baker and B.S. Prabhakar, 2012. Human Monoclonal antibodies against highly conserved HR1 and HR2 domains of the SARS-CoV spike protein are more broadly neutralizing. PloS One, 7: e50366-e50366. DOI: 10.1371/journal.pone.0050366

Fouchier, R.A., T. Kuiken, Martin Schutten, G.V. Amerongen and K. Stohr et al., 2003. Aetiology: Koch's postulates fulfilled for SARS virus. Nature, 423: 240-240. DOI: 10.1038/423240a

Frieman, M., D. Basu, K. Matthews, J. Taylor and G. Jones et al., 2011. Yeast based small molecule screen for inhibitors of SARS-CoV. PloS One, 6: e28479-e28479. 10.1371/journal.pone.0028479

Ghosh, A.K., G. Gong, V. Grum-Tokars, D.C. Mulhearn and S.C. Baker et al., 2008. Design, synthesis and antiviral efficacy of a series of potent chloropyridyl ester-derived SARS-CoV 3CLpro inhibitors. Bioorganic Med. Chem. Lett., 18: 5684-5688. DOI: 10.1016/j.bmcl.2008.08.082

Ghosh, A.K., J. Takayama, Y. Aubin, K. Ratia and R. Chaudhuri et al., 2009. Structure-Based design, synthesis and biological evaluation of a series of novel and reversible inhibitors for the severe acute respiratory syndrome-coronavirus papain-like protease. J. Med. Chem., 52: 5228-5240. DOI: $10.1021 / \mathrm{jm} 900611 \mathrm{t}$
Ghosh, A.K., K. Xi, V. Grum-Tokars, X. Xu and K. Ratia et al., 2007. Structure-based design, synthesis and biological evaluation of peptidomimetic SARSCoV 3CLpro inhibitors. Bioorganic Med. Chem. Lett., 17: 5876-5880. PMID: 17855091

Goetz, D.H., Y. Choe, E. Hansell, Y.T. Chen and M. McDowell et al., 2007. Substrate specificity profiling and identification of a new class of inhibitor for the major protease of the SARS coronavirus. Biochemistry, 46: 8744-8752. PMID: 17605471

Graham, R.L., M.M. Becker, L.D. Eckerle, M. Bolles and M.R. Denison et al., 2012. A live, impairedfidelity coronavirus vaccine protects in an aged, immunocompromised mouse model of lethal disease. Nature Med., 18: 1820-1826. DOI:10.1038/nm.2972

Groneberg, D.A., S.M. Poutanen, D.E. Low, H. Lode and T. Welte et al., 2005. Treatment and vaccines for severe acute respiratory syndrome. Lancet Infect. Dis., 5: 147-155. DOI: 10.1016/S14733099(05)01307-1

Guan, Y., B.J. Zheng, J.S.M. Peiris, Y.J. Guan and L.J. Zhang et al., 2003. Isolation and characterization of viruses related to the SARS coronavirus from animals in southern China. Science, 302: 276-278. DOI: $10.1126 /$ science. 1087139

Haga, S., N. Nagata, N. Yamamoto T. Sata and N. Yamamoto et al., 2010. TACE antagonists blocking ACE2 shedding caused by the spike protein of SARS-CoV are candidate antiviral compounds. Antivir. Res., 85: 551-555. DOI: 10.1016/j.antiviral.2009.12.001

Han, D.P., A. Penn-Nicholson and M.W. Cho, 2006. Identification of critical determinants on ACE2 for SARS-CoV entry and development of a potent entry inhibitor. Virology, 350: 15-25. DOI: 10.1016/j.virol.2006.01.029

He, R., A. Adonov, J. Cao, T. Cutts and E. Grudesky et al., 2004. Potent and selective inhibition of SARS coronavirus replication by aurintricarboxylic acid. Biochem. Biophys. Res. Commun., 320: 1199-1203. DOI: 10.1016/j.bbrc.2004.06.076

Hoever, G. and L. Baltina, 2005. Antiviral activity of glycyrrhizic acid derivatives against SARScoronavirus. J. Med. Chem., 48: 1256-1259. DOI: 10.1021/jm0493008

Hu, M.C., T. Jones, R.T. Kenney, D.L. Barnard and D.S. Burt et al., 2007. Intranasal protollin-formulated recombinant SARS S-protein elicits respiratory and serum neutralizing antibodies and protection in mice. Vaccine, 25: 6334-6340. PMID: 17640780 
Imai, Y., K. Kuba, S. Rao Y. Huan and F. Guo et al., 2005. Angiotensin-converting enzyme 2 protects from severe acute lung failure. Nature, 436: 112116. DOI: $10.1038 /$ nature 03712

Jang, K.J., N.R. Lee, W.S. Yeo, Y.J. Jeong and D.E. Kim et al., 2008. Isolation of inhibitory RNA aptamers against Severe Acute Respiratory Syndrome (SARS) coronavirus NTPase/Helicase. Biochem. Biophys. Res. Commun., 366: 738-744. DOI: 10.1016/j.bbrc.2007.12.020

Jaume, M., M.S. Yip, C.Y. Cheung, H.L. Leung and P.H. $\mathrm{Li}$ et al., 2011. Anti-severe acute respiratory syndrome coronavirus spike antibodies trigger infection of human immune cells via a $\mathrm{pH}$-and cysteine protease-independent FcgammaR pathway. J. Virol., 85: 10582-10597. DOI: 10.1128/JVI.00671-11

Kaeppler, U., N. Stiefl, A. Breuning, R. Vicik and C. Schmuck et al., 2005. A new lead for nonpeptidic active-site-directed inhibitors of the severe acute respiratory syndrome coronavirus main protease discovered by a combination of screening and docking methods. J. Med. Chem., 48: 6832-6842. DOI: $10.1021 / \mathrm{jm} 0501782$

Kam, Y.W., F. Kien, A. Roberts, Y.C. Cheung and L. Vogel et al., 2007. Antibodies against trimeric S glycoprotein protect hamsters against SARS-CoV challenge despite their capacity to mediate Fc $\gamma$ RIIdependent entry into B cells in vitro. Vaccine, 25: 729-740. DOI: 10.1016/j.vaccine.2006.08.011

Kao, R.Y., A.P. To, L.W.Y. Ng, W.H.W. Tsui and T.S.W. Lee et al., 2004. Characterization of SARS$\mathrm{CoV}$ main protease and identification of biologically active small molecule inhibitors using a continuous fluorescence-based assay. FEBS Lett., 576: 325-330. DOI: 10.1016/j.febslet.2004.09.026

Keum, Y.S. and Y.J. Jeong, 2012. Development of chemical inhibitors of the SARS coronavirus: Viral helicase as a potential target. Biochem. Pharmacol., 84: 1351-1358. DOI: 10.1016/j.bcp.2012.08.012

Keyaerts, E., L. Vijgen, P. Maes, J. Neyts and M.V. Ranst et al., 2004. In vitro inhibition of severe acute respiratory syndrome coronavirus by chloroquine. Biochem. Biophys. Res. Commun., 323: 264-268. DOI: 10.1016/j.bbrc.2004.08.085

Ksiazek, T.G., D. Erdman, D. Erdman, C.S. Goldsmith and S.R. Zaki et al., 2003. A novel coronavirus associated with severe acute respiratory syndrome. New England J. Med., 348: 1953-1966. DOI: 10.1056/NEJMoa030781
Kuo, C.J., H.G. Liu, Y.K. Lo, C.M. Seong and K.I. Lee et al., 2009. Individual and common inhibitors of coronavirus and picornavirus main proteases. FEBS Lett., 583: 549-555. DOI: 10.1016/j.febslet.2008.12.059

Lai, S.T., 2005. Treatment of severe acute respiratory syndrome. Eur. J. Clin. Microbiol. Infect. Dis., 24: 583-591. PMID: 16172857

Lamirande, E.W., M.L. DeDiego, A. Roberts, J.P. Jackson and E. Alvarez et al., 2008. A live attenuated severe acute respiratory syndrome coronavirus is immunogenic and efficacious in golden syrian hamsters. J. Virol., 82: 7721-7724. DOI: $10.1128 /$ JVI.00304-08

Lang, J., N. Yang, J. Deng, K. Liu and P. Yang et al., 2011. Inhibition of SARS pseudovirus cell entry by lactoferrin binding to heparan sulfate proteoglycans. PloS One, 6: e23710-e23710. DOI: 10.1371/journal.pone.0023710

Lau, C.W.A., L.K.Y. So and L.Y.C. Yam, 2006. Response to published article. J. Infect., 52: 309310. DOI: $10.1016 /$ j.jinf.2005.08.004

Lee, C.C., C.J. Kuo, M.F. Hsu, P.H. Liang and J.M. Fang et al., 2007. Structural basis of mercury-and zincconjugated complexes as SARS-CoV 3C-like protease inhibitors. FEBS Lett., 581: 5454-5458. DOI: 10.1016/j.febslet.2007.10.048

Lee, C.C., C.J. Kuo, Y.C. Tsui, H.C. Chen and P.H. Liang et al., 2009. Structural basis of inhibition specificities of 3C and 3C-like proteases by zinccoordinating and peptidomimetic compounds. J. Biol. Chem., 284: 7646-7655. DOI: 10.1074/jbc.M807947200

Lee, T.W., M.M. Cherney, K.E. James, J.C. Powers and M.N.G. James et al., 2005. Crystal structures of the main peptidase from the SARS coronavirus inhibited by a substrate-like aza-peptide epoxide. J. Mol. Biol., 353: 1137-1151. DOI: 10.1016/j.jmb.2005.09.004

Li, T. and Y. Zhang, L. Fu, C. Yu and X. Li et al., 2005a. siRNA targeting the leader sequence of SARS-CoV inhibits virus replication. Gene Therapy, 12: 751-761. DOI: 10.1038/sj.gt.3302479

Li, W., Z. Shi, L.F. Wang, W. Ren and J.H. Epstein et al., 2005b. Bats are natural reservoirs of SARS-like coronaviruses. Science, 310: 676-679. DOI: 10.1126/science. 1118391

Liang, P.H., 2006. Characterization and inhibition of SARS-coronavirus main protease. Curr. Topics Med. Chem., 6: 361-376. DOI: $10.2174 / 156802606776287090$ 
Lin, C.W., F.J. Tsai, C.H. Tsai, C.C. Lai and L. Wan et al., 2005. Anti-SARS coronavirus 3C-like protease effects of Isatis indigotica root and plant-derived phenolic compounds. Antivir. Res., 68: 36-42. DOI: 10.1016/j.antiviral.2005.07.002

Lin, J.T., J.S. Zhang, N. Wang, J.T. Chen and X. Chen et al., 2007. Safety and immunogenicity from a phase I trial of inactivated severe acute respiratory syndrome coronavirus vaccine. Antivir. Ther., 12: 1107-1113. PMID: 18018769

Lu, G. and D. Liu, 2012. SARS-like virus in the Middle East: A truly bat-related coronavirus causing human diseases. Protein Cell, 3: 803-805. DOI: 10.1007/s13238-012-2811-1

Ma, X.Z., A. Bartczak, J. Zhang, R. Khattar and M.F. Liu et al., 2010. Proteasome inhibition in vivo promotes survival in a lethal murine model of severe acute respiratory syndrome. J. Virol., 84: 1241912428. DOI: 10.1128/JVI.01219-10

Martin, J.E., M.K. Loudera, L.A. Holmana, I.J. Gordona and M.E. Enama et al., 2008. A SARS DNA vaccine induces neutralizing antibody and cellular immune responses in healthy adults in a Phase I clinical trial. Vaccine, 26: 6338-6343. DOI: 10.1016/j.vaccine.2008.09.026

Millet, J.K., F. Kien, C.Y. Heung, Y.L. Siu and W.L. Chan et al., 2012. Ezrin Interacts with the SARS coronavirus spike protein and restrains infection at the entry stage. PloS One, 7: e49566-e49566. DOI: 10.1371/journal.pone.0049566

Morgenstern, B., M. Michaelis, P.C. Baer and H.W. Doerr, 2005. Ribavirin and interferon- $\beta$ synergistically inhibit SARS-associated coronavirus replication in animal and human cell lines. Biochem. Biophys. Res. Commun., 326: 905-908. DOI: 10.1016/j.bbrc.2004.11.128

Mukherjee, P., F. Shah, P. Desai and M. Avery 2011. Inhibitors of SARS-3CL ${ }^{\text {pro }}$ Virtual screening, biological evaluation and molecular dynamics simulation studies. J. Chem. Inform. Model., 51: 1376-1392. DOI: 10.1021/ci1004916

Mukherjee, P., P. Desai, L. Ross, E.L. White and M.A. Avery et al., 2008. Structure-based virtual screening against SARS-3CL(pro) to identify novel nonpeptidic hits. Bioorganic Med. Chem., 16: 41384149. DOI: $10.1016 / \mathrm{j} . \mathrm{bmc} .2008 .01 .011$

Napoli, P.D., P.D. Giovanni, M.A. Gaeta, A.A. Taccardi, 2007. Trimetazidine and reduction in mortality and hospitalization in patients with ischemic dilated cardiomyopathy: A post hoc analysis of the villa pini d'abruzzo trimetazidine trial. J. Cardiovascular Pharmacol., 50: 585-589. DOI: 10.1097/FJC.0b013e31814fa9cb
Neuman, B.W. and D.A. Stein, A.D. Kroeker, M.J. Churchill and A.M. Kim et al., 2005. Inhibition, escape and attenuated growth of severe acute respiratory syndrome coronavirus treated with antisense morpholino oligomers. J. Virol., 79: 96659676. DOI: 10.1128/JVI.79.15.9665-9676.2005

Nguyen, T.T., H.J. Ryu, S.H. Lee, S. Hwang and V. Breton et al., 2011. Virtual screening identification of novel severe acute respiratory syndrome 3C-like protease inhibitors and in vitro confirmation. Bioorganic Med. Chem. Lett., 21: 3088-3091. DOI: 10.1016/j.bmcl.2011.03.034

Nguyen, T.T., H.J. Woo, H.K. Kang, V.D. Nguyen and Y.M. Kim et al., 2012. Flavonoid-mediated inhibition of SARS coronavirus 3C-like protease expressed in Pichia pastoris. Biotechnol. Lett., 34: 831-838. DOI: 10.1007/s10529-011-0845-8

Ni, L., J. Zhu, J. Zhanga, M. Yana and G.F. Gaoa et al., 2005. Design of recombinant protein-based SARS$\mathrm{CoV}$ entry inhibitors targeting the heptad-repeat regions of the spike protein S2 domain. Biochem. Biophys. Res. Commun., 330: 39-45. DOI: 10.1016/j.bbrc.2005.02.117

Olsen, C.W., W.V. Corapi, R.H. Jacobson R.A. Simkins and L.J. Saif et al., 1993. Identification of antigenic sites mediating antibody-dependent enhancement of feline infectious peritonitis virus infectivity. J. General Virol., 74: 745-749. DOI: 10.1099/00221317-74-4-745

Pfefferle, S., J. Schopf, M. Kögl, C.C. Friedel and M.A. Müller et al., 2011. The SARS-coronavirus-host interactome: Identification of cyclophilins as target for pan-coronavirus inhibitors. PLoS Pathogens, 7: e1002331-e1002331.

DOI: 10.1371/journal.ppat.1002331

Plewczynski, D., M. Hoffmann, M.V. Grotthuss, K. Ginalski and L. Rychewski et al., 2007. In silico prediction of SARS protease inhibitors by virtual high throughput screening. Chem. Biol. Drug Des., 69: 269-279. PMID: 17461975

Qin, Z.L., P. Zhao, X.L. Zhang, J.G. Yu and M.M. Cao et al., 2004. Silencing of SARS-CoV spike gene by small interfering RNA in HEK 293T cells. Biochem. Biophys. Res. Commun., 324: 1186-1193. PMID: 15504339

Ramajayam, R., K.P. Tan and P.H. Liang, 2011. Recent development of $3 \mathrm{C}$ and $3 \mathrm{CL}$ protease inhibitors for anti-coronavirus and anti-picornavirus drug discovery. Biochem. Soc. Trans., 39: 1371-1375. DOI: 10.1042/BST0391371 
Ramajayam, R., K.P. Tan, H.G. Liub and P.H. Liang, 2010. Synthesis, docking studies and evaluation of pyrimidines as inhibitors of SARS-CoV 3CL protease. Bioorganic Med. Chem. Lett., 20: 35693572. DOI: 10.1016/j.bmcl.2010.04.118

Ratia, K., S. Pegan, K. Sleeman, M. Coughlin and S. Baliji et al., 2008. A noncovalent class of papainlike protease/deubiquitinase inhibitors blocks SARS virus replication. Proc. Natl. Acad. Sci. USA., 105: 16119-16124. DOI: 10.1073/pnas.0805240105

Regnier, T., D. Sarma, K. Hidaka, U. Bacha and E. Freire et al., 2009. New developments for the design, synthesis and biological evaluation of potent SARS-CoV 3CL(pro) inhibitors. Bioorganic Med. Chem. Lett., 19: 2722-2727. DOI: 10.1016/j.bmcl.2009.03.118

Roberts, A., E.W. Lamirande, L. Vogel, J.P. Jackson and C.D. Paddock et al., 2008. Animal models and vaccines for SARS-CoV infection. Virus Res., 133: 20-32. PMID: 17499378

Roper, R.L. and K.E. Rehm, 2009. SARS vaccines: Where are we? Expert Rev. Vaccines, 8: 887-898. PMID: 19538115

Rota, P.A., M.S. Oberste, W.A. Nix, R. Campagnoli and J.P. Icenogle et al., 2003. Characterization of a novel coronavirus associated with severe acute respiratory syndrome. Science, 300: 1394-1399. DOI: $10.1126 /$ science. 1085952

Ruan, Y.J., C.L. Wei, H. Thoreau, S.T. Su and J.M. Chia et al., 2003. Comparative full-length genome sequence analysis of 14 SARS coronavirus isolates and common mutations associated with putative origins of infection. Lancet, 361: 1779-1785. PMID: 12781537

Ryu, Y.B., S.J. Park, Y.M. Kim, J.Y. Lee and W.D. Seo et al., 2010. SARS-CoV 3CLpro inhibitory effects of quinone-methide triterpenes from Tripterygium regelii. Bioorganic and Med. Chem. Lett., 20: 18731876. DOI: $10.1016 /$ j.bmcl.2010.01.152

Saijo, M., S. Morikawa, S. Fukushi, T. Mizutani and H. Hasegawa et al., 2005. Inhibitory effect of mizoribine and ribavirin on the replication of Severe Acute Respiratory Syndrome (SARS)-associated coronavirus. Antivir. Res., 66: 159-163. PMID: 15911031

Sainz, B.J., E.C. Mossel, W.R. Gallaher, W.C. Wimley and C.J. Peters et al., 2006. Inhibition of severe acute respiratory syndrome-associated coronavirus (SARS-CoV) infectivity by peptides analogous to the viral spike protein. Virus Res., 120: 146-155. PMID: 16616792
Schwarz, S. and K. Wang, 2011. Emodin inhibits current through SARS-associated coronavirus 3a protein. Antiviral Res., 90: 64-69. DOI: 10.1016/j.antiviral.2011.02.008

See, R.H., A.N. Zakhartchouk, M. Petric, D.J. Lawrence and C.P. Mok et al., 2006. Comparative evaluation of two Severe Acute Respiratory Syndrome (SARS) vaccine candidates in mice challenged with SARS coronavirus. J. General Virol., 87: 641-650. PMID: 16476986

See, R.H., M. Petric, D.J. Lawrence, C.P. Mok and T. Roweet al., 2008. Severe acute respiratory syndrome vaccine efficacy in ferrets: Whole killed virus and adenovirus-vectored vaccines. J. Gen. Virol., 89: 2136-2146. DOI: 10.1099/vir.0.2008/001891-0

Shao, Y.M., W.B. Yang, T.H. Kuo, K.C. Tsai and C.H. Lin et al., 2008. Design, synthesis and evaluation of trifluoromethyl ketones as inhibitors of SARS-CoV 3CL protease. Bioorganic Med. Chem., 16: 46524660. DOI: 10.1016/j.bmc.2008.02.040

Shim, B.S., K. Stadler, H.H. Nguyen, C.H. Yun and D.W. Kim et al., 2012. Sublingual immunization with recombinant adenovirus encoding SARS-CoV spike protein induces systemic and mucosal immunity without redirection of the virus to the brain. Virol. J., 19: 215-215. DOI: 10.1186/1743422X-9-215

Simmons, G., D.N. Gosalia, A.J. Rennekamp, J.D. Reeves and S.L. Diamond et al., 2005. Inhibitors of cathepsin L prevent severe acute respiratory syndrome coronavirus entry. Proc. Natl. Acad. Sci. USA., 102: 11876-11881. DOI: 10.1073/pnas.0505577102

Smith, S.B., W. Dampier, A. Tozeren, J.R. Brown and M. Magid-Slav, 2012. Identification of common biological pathways and drug targets across multiple respiratory viruses based on human host gene expression analysis. PloS One, 7: e33174-e33174. DOI: 10.1371/journal.pone.0033174

Stockman, L.J., R. Bellamy and P. Garner, 2006. SARS: Systematic review of treatment effects. PLoS Med., 3: e343- e343. DOI:10.1371/journal.pmed.0030343

Struck, A.W., M. Axmann, S. Pfefferleb, C. Drosten and B. Meyera, 2012. A hexapeptide of the receptorbinding domain of SARS corona virus spike protein blocks viral entry into host cells via the human receptor ACE2. Antivir. Res., 94: 288-296. DOI: 10.1016/j.antiviral.2011.12.012 
Subbarao, K., J. McAuliffe, L. Vogel, G. Fahle and S. Fischer et al., 2004. Prior infection and passive transfer of neutralizing antibody prevent replication of severe acute respiratory syndrome coronavirus in the respiratory tract of mice. J. Virol., 78: 35723577. DOI: 10.1128/JVI.78.7.3572-3577.2004

Sunwoo, H.H., A. Palaniyappan, A. Ganguly, P.K. Bhatnagar and D. Das et al., 2012. Quantitative and sensitive detection of the SARS-CoV spike protein using bispecific monoclonal antibody-based enzyme-linked immunoassay. J. Virol. Meth., 187: 72-78 DOI: 10.1016/j.jviromet.2012.09.006

Tang, Q. and B. Li, 2008. Application of siRNA against SARS in the rhesus macaque model. Methods Mol. Biol., 442: 139-158. DOI: 10.1007/978-1-59745191-8 11

Tseng, C.T. ., E. Sbrana, N. Iwata-Yoshikawa, P.C. Newman and T. Garron et al., 2012. Immunization with SARS coronavirus vaccines leads to pulmonary immunopathology on challenge with the SARS virus. PloS One, 7: e35421-e35421. DOI: 10.1371/journal.pone.0035421

Tsui, S.K., S.S. Chim and Y.M.D. Lo, 2003. Coronavirus genomic-sequence variations and the epidemiology of the severe acute respiratory syndrome. New England J. Med., 349: 187-188. DOI: 10.1056/NEJM200307103490216

Ujike, M., H. Nishikawa, A. Otaka, N. Yamamoto and N. Yamamoto et al., 2008. Heptad repeat-derived peptides block protease-mediated direct entry from the cell surface of severe acute respiratory syndrome coronavirus but not entry via the endosomal pathway. J. Virol., 82: 588-592. DOI: 10.1128/JVI.01697-07

Verschueren, K.H., K. Pumpor, S. Anemüller, S. Chen and J.R. Mesters et al., 2008. A structural view of the inactivation of the SARS coronavirus main proteinase by benzotriazole esters. Chem. Biol., 15: 597-606. DOI: 10.1016/j.chembiol.2008.04.011

Vincent, M.J., E. Bergeron, S. Benjannet, B.R. Erickson and P.E. Rollin et al., 2005. Chloroquine is a potent inhibitor of SARS coronavirus infection and spread. Virol. J., 2: 69-69. DOI: 10.1186/1743-422X-2-69

Wang, S.Q., Q.S. Du, K. Zhao, A.X. Li and D.Q. Wei et al., 2007. Virtual screening for finding natural inhibitor against cathepsin-L for SARS therapy. Amino Acids, 33: 129-135. PMID: 16998715

Weingartl, H., M. Czub, S. Czub, J. Neufeld and P. Marszal et al., 2004. Immunization with modified vaccinia virus Ankara-based recombinant vaccine against severe acute respiratory syndrome is associated with enhanced hepatitis in ferrets. J. Virol., $\quad 78$ : 12672-12676. DOI: 10.1128/JVI.78.22.12672-12676
$\mathrm{Wu}, \mathrm{C} . J$. and H.W. Huang, 2005. Inhibition of SARSCoV replication by siRNA. Antiviral Res., 65: 4548. DOI: 10.1016/j.antiviral.2004.09.005

Wu, C.J., J.T. Jan, C.M. Chen, H.P. Hsieh and D.R. Hwang et al., 2004a. Inhibition of severe acute respiratory syndrome coronavirus replication by niclosamide. Antimicrob. Agents Chemother., 48: 2693-2696. DOI: 10.1128/AAC.48.7.2693-2696.2004

Wu, C.Y., J.T. Jan, S.H. Ma, C.J. Kuo and H.F. Juan et al., 2004b. Small molecules targeting severe acute respiratory syndrome human coronavirus. Proc. Natl. Acad. Sci. USA., 101: 10012-10017. DOI: 10.1073/pnas.0403596101

Wu, X., G. Cheng, M. Wang, X. Zhou and L. He et al., 2003. Establishment of a fluorescent polymerase chain reaction method for the detection of the SARS-associated coronavirus and its clinical application. Chin. Med. J., 116: 988-990. PMID: 12890368

Yam, W.C., K.H. Chan, Y. Guan, K.Y. Yuen and W.H. Seto et al., 2003. Evaluation of reverse transcription-PCR assays for rapid diagnosis of severe acute respiratory syndrome associated with a novel coronavirus. J. Clin. Microbiol., 41: 45214524. DOI: 10.1128/JCM.41.10.4521-4524.2003

Yang, C.W. and Y.Z. Lee, I.J. Kang, D.L. Barnard and J.T. Jan et al., 2010. Identification of phenanthroindolizines and phenanthroquinolizidines as novel potent anti-coronaviral agents for porcine enteropathogenic coronavirus transmissible gastroenteritis virus and human severe acute respiratory syndrome coronavirus. Antiviral Res., 88: 160-168. DOI: 10.1016/j.antiviral.2010.08.009

Yang, H., W. Xie, X. Xue, K. Yang and J. Ma et al., 2005a. Design of wide-spectrum inhibitors targeting coronavirus main proteases. PLoS Biol., 3: e324e324. DOI: 10.1371/journal.pbio.003032

Yang, N., J.A. Tanner, Z. Wang, J.D. Huang and B.J. Zheng et al., 2007. Inhibition of SARS coronavirus helicase by bismuth complexes. Chem. Commun., 42: 4413-4415. DOI: 10.1039/B709515E

Yang, Z.Y., H.C. Werner, W.P. Kong, K. Leung and E. Traggiai et al., 2005b. Evasion of antibody neutralization in emerging severe acute respiratory syndrome coronaviruses. Proc. Natl. Acad. Sci. USA., 102: 797-801. DOI: 10.1073/pnas.0409065102

Yang, Z.Y., W.P. Kong, Y. Huang, A. Roberts and B.R. Murphy, 2004. A DNA vaccine induces SARS coronavirus neutralization and protective immunity in mice. Lett. Nature, 428: 561-564. DOI: 10.1038 /nature 02463 
Yi, L., Z. Li, K. Yuan, X. Qu and J. Chen et al., 2004. Small molecules blocking the entry of severe acute respiratory syndrome coronavirus into host cells. J. Virol., 78: 11334-11339. DOI: 10.1128/JVI.78.20.11334-11339.2004

Zakhartchouk, A.N., S. Viswanathan, J.B. Mahony, J. Gauldie and L.A. Babiuk et al., 2005. Severe acute respiratory syndrome coronavirus nucleocapsid protein expressed by an adenovirus vector is phosphorylated and immunogenic in mice. J. Gen. Virol., 86: 211-215. DOI: 10.1099/vir.0.80530-0

Zhang, J., C. Huitema, C. Niuc, J. Yinc and M.N.G. James et al., 2008. Aryl methylene ketones and fluorinated methylene ketones as reversible inhibitors for Severe Acute Respiratory Syndrome (SARS) 3C-like proteinase. Bioorganic Chem., 36: 229-240. DOI: 10.1016/j.bioorg.2008.01.001

Zhang, J., H.I. Pettersson, C. Huitema, C. Niu and J. Yin et al., 2007. Design, synthesis and evaluation of inhibitors for severe acute respiratory syndrome $3 \mathrm{C}$ like protease based on phthalhydrazide ketones or heteroaromatic esters. J. Med. Chem., 50: 18501864. DOI: $10.1021 / \mathrm{jm} 061425 \mathrm{k}$
Zhao, J. and S. Perlman, 2010. T cell responses are required for protection from clinical disease and for virus clearance in severe acute respiratory syndrome coronavirus-infected mice. J. Virol., 84: 9318-9325. DOI: 10.1128/JVI.01049-10

Zhao, J., C. Wohlford-Lenane, J. Zhao, E. Fleminga and T.E. Lane et al., 2012. Intranasal treatment with Poly $(\mathrm{I} \cdot \mathrm{C})$ protects aged mice from lethal respiratory virus infections. J. Virol., 86: 11416-11424. DOI: 10.1128/JVI.01410-12

Zhao, P. and Z.L. Qin, 2005. Small interfering RNA inhibits SARS-CoV nucleocapsid gene expression in cultured cells and mouse muscles. FEBS Lett., 579: 2404-2410. DOI: 10.1016/j.febslet.2005.02.080

Zhou, Y., J. Agudelo, D.H. Goetzc, E. Hanselld and Y.T. Chen et al., 2011. Inhibitors of SARS-CoV entryIdentification using an internally-controlled dual envelope pseudovirion assay. Antiviral Res., 92: 187-194. DOI: 10.1016/j.antiviral.2011.07.016

Zhuang, M. and H. Jiang, 2009. Procyanidins and butanol extract of Cinnamomi Cortex inhibit SARS$\mathrm{CoV}$ infection. Antiviral Res., 82: 73-81. DOI: 10.1016/j.antiviral.2009.02.001 